\title{
Educational Research Training in Teacher Training Programs: The Views of Future Teachers
}

\author{
Haylen Perines ${ }^{1}$ \\ ${ }^{1}$ University of La Serena, Chile \\ Correspondence: Haylen Perines, Raúl Bitrán 1305, La Serena, Chile. E-mail: haylen.perines@userena.cl
}

Received: June 20, 2020

Accepted: September 15, 2020

Online Published: December 26, 2020

doi:10.5539/ies.v14n1p76

URL: https://doi.org/10.5539/ies.v14n1p76

\begin{abstract}
The objectives of this study were to explore teacher student's views on the research training they receive and know their suggestions for improving it. This was a qualitative study conducted on students in the teacher training programs of a Chilean public university who were distributed into nine focus groups. The findings showed that the students have a rather critical view about the training they receive, particularly due to the lack of continuity of research-related courses and their limited participation in research activities. Regarding how to improve their training, the students suggest providing one research-related course each year, having researchers as teachers, and giving greater visibility to the educational research produced within their university. The study concludes that it is important to promote participation in educational research and that university teacher educators and the entire university community must adopt a broad-ranging view on this subject.
\end{abstract}

Keywords: educational research, future teachers, pedagogy, university

\section{Introduction}

The presence and importance of educational research in professional training is an issue that has attracted the interest not only of governments, political decision-makers, and researchers all over the world (Griffioen, Groen, \& Nak, 2019), but also of teachers and students. Its growing relevance is linked to one of the roles of higher education, namely, achieving the students' transformation through their interaction with research and knowledge (Ashwin, 2014).

Teacher training has not remained indifferent; quite the contrary, educational research is gaining stronger relevance within teacher training programs. This increased interest has motivated studies into the future teachers' views on educational research (Haberfellner \& Fenz, 2017; Perines \& Murillo, 2017) and the students' views on research-related courses (van der Linden, Bakx, Ros, Beijaard, \& Vermeulen, 2012). Such studies and relevant theoretical reviews have found that educational research is poorly represented in teacher education curricula (Perines, 2018; Perines \& Campaña, 2019) to the point of being mostly invisible (Cain \& Allan, 2017). They also note the importance of achieving early literacy in educational research during the first years of study (Anwaruddin \& Pervin, 2015; van der Linden et al., 2012) and that research activities that are linked to the teaching practice are more relevant for students.

Despite the growing interest in this subject, more research into the views that future teachers hold about the educational research training they receive is needed. Moreover, very little has been written about the students' suggestions for improving this type of training. This study aims at identifying the views that future teachers hold about the research training they receive and knowing their suggestions for improving it.

\subsection{Theoretical Framework}

To chart the existing studies on students' views about their educational research training and their suggestions for improving it, the following theoretical review is organized based on the most relevant themes identified in the literature. These themes are the relevance of the curriculum and the professionals responsible for it, and the approach used in the research activities performed by the students.

\subsection{Relevance of the Curriculum and of the Professionals Responsible for It}

A widely discussed topic in the prevailing literature is the relevance of the teaching education curriculum in the views expressed by students. Studying curriculum design is a complex but necessary task (Young, 2014). Student 
participation in research and other related activities depends not only on personal factors, such as motivation and initiative, but also on structural ones, such as curriculum design and the strategic actions taken by university faculties (Agud \& Ion, 2019).

In this regard, Barnett (2009) maintains that curriculum design should eventually provide answers to two fundamental questions: what should be taught? and how should it be taught? According to this author, these two questions help to link the teaching methods with the epistemological activity that is typical of knowledge building. Along the same line, Neary and Winn (2009) propose a learning experience where students and teachers can collaborate together in research activities to "democratize the process of knowledge production at the level of society" (p. 132).

In some studies, the future teachers suggest that teacher training programs should be modified to include more educational research, ideally from the first years of study (e.g., Demircioglu, 2008; MacDonald, Badger, \& White, 2001; Perines \& Murillo, 2017). Many teacher students agree that having one or two courses almost at the end of the process does not promote the acquisition of the educational research knowledge necessary for it to become a relevant activity in their future teaching practice.

Another relevant aspect linked to the curricula has to do with the people responsible for their design and implementation. According to Griffioen et al. (2019), the aspects that must be taken into consideration when implementing research in curricula also make implicit reference to the competences of teacher educators and curriculum designers. If we want to integrate research into the curriculum, curriculum designers must be prepared to do that. A high-quality curriculum requires curriculum designers who have design experience, subject-matter knowledge, and pedagogical knowledge (Huizinga, Handelzalts, Nieveen, \& Voogt, 2014).

In addition, the evidence shows that bringing research closer to teacher training programs requires implementing changes from the first years of study. In this line, van der Linden et al. (2012) studied students' attitudes toward an introductory research course. In this study, the course aspects most valued by the students were working in pairs, in groups, and in realistic tasks based on examples derived from the teaching practice. The authors conclude that prospective teachers need to develop a positive attitude towards research for their own professional benefit and that research should be taught from the first years of study. This is essential for the role research will play in their future professional career. Similarly, in McCartney, Marwick, Hendry, and Ferguson (2018), the future teachers express that participating in educational research workshops had positive effects in them. However, they consider educational research to be an inaccessible tool and would like this to change.

\subsection{Approach to the Research Activities That Students Could Perform}

Participation in research activities seems to be a useful and beneficial strategy for improving the professional competences of teacher students (Guilbert, Lane, \& Van Bergen, 2016). Research activities help students to interpret the research produced by other people (Reis-Jorge, 2005; Ion, 2014) and enable them to be more aware of their own learning (Todd, Bannister, \& Clegg, 2004). Goodyear and Zenios (2007) view student participation in research as a way of developing the students' ability to understand and participate in different knowledge building settings.

Similarly, Levy and Petrulis (2012) believe that educational research activities help students to develop their self-confidence and independent learning, an understanding of their knowledge and its source, a better understanding of how research is conducted (which may help to optimize the relationship with the researchers in their departments), and the development of thinking abilities, such as analytical or problem-solving skills.

However, the prevailing literature has shown that not all research activities are equally relevant for future teachers. In the above-mentioned work by Levy and Petrulis (2012), first-year students were found to understand and experience research differently based on the four quadrants of Jenkins and Healey's model (2007). Research as "information gathering" and "exploration of other people's ideas" was associated with learning based on knowledge acquisition, whereas research as "evidence and development of the student's own ideas" and "discovering" was associated with an emerging notion of engagement in the creation of knowledge. Similarly, the students described their research experiences as a tool to promote their own intellectual and personal development. This research also showed that tasks that are more limited in nature may offer benefits such as engagement, motivation and self-confidence. However, research activities that favor greater independence encourage students to establish their own lines of research, which may greatly promote empowerment.

Following an approach that emphasizes the link with practice, Damşa (2018) conducts a study on education students, who were asked to work on research activities as part of school internships. The findings showed that research training activities that are linked with practice are more relevant for students since they enable them to 
build their own repertoire of knowledge and teaching practices. According to the author, these activities also pose challenges, such as having to balance the needs of the teaching practice with the expectations of teacher teaching programs.

Sometimes educational research is given due relevance as part of teacher training, but then it is shunt aside when the practice demands starts to occupy more time and become a priority. In this context, the title of the article by van Katwijk, Berry, Jansen and van Veen (2019) makes perfect sense: "It's important, but I'm not going to keep doing it!" (p.1). This research focused on teacher training and used a mixed-focus approach on education students and their educators. The results showed that the future teachers have positive views about the educational research training they have received, especially as a tool for professional development and teacher empowerment. Among the aspects of note, the students point out that they have acquired the habit of inquiry and that they now have a more critical view of the teaching practice. Their answers contain several comments about the way of conducting research — linking theory and practice — and about the intellectual habit of research as a tool to reflect and be more open-minded. Despite these positive views, many participants expressed they did not expect to continue doing research in the future due mainly to practice demands. This should motivate a serious analysis of what happens with educational research during the teaching practice. In this same respect, some education students maintain that conducting a research project takes away time from the more practical aspects of the curriculum (Dunn, Harrison, \& Coombe, 2008; Ulvik, 2014). In Puustinen, Säntti, Koski, and Tammi (2018), the authors conclude that students are skeptical of the importance of research for the teaching practice. Aspfors and Eklund (2017) reach similar conclusions when they point out that some of the education students in Finland and Norway have difficulty identifying potential daily-practice applications of research.

This theme relates to some of the criticisms evidenced by studies conducted on school teachers, many of whom express that they lack the conditions to conduct research due to lack of time and in some cases training (Damşa, 2018; Murillo, Perines, \& Lomba, 2017; Perines \& Murillo, 2017a, 2017b).

\section{Methods}

The objectives of this research are to explore the views of future teachers about the research training they are receiving and know their suggestions for improving it. For the study, a qualitative approach is used based on its exploratory rather than quantifying nature. The purpose is to have an in-depth look at the views of education students through the meanings. "The qualitative researcher starts with a question (...): what are the meanings that these people use to organize their behavior and interpret the events on which their experiences are based?" (Rodríguez, Gil, \& García, 1999, p. 102). These meanings expressed by teacher students are the precise focus of this study.

The research participants are teacher students of a Chilean public university who are in the final semester of the program, very close to starting their professional careers. The students were assigned to nine focus groups with eight participants each. The university where the research was conducted offers 11 teaching training programs distributed across three faculties (Economics and Social Sciences, Arts and Humanities, and Sciences), providing a favorable and interesting scenario to collect information on the subject.

Taking into account the available universe of students, participants were screened using a stratified non-probabilistic sampling method. The two strata selected were the students' educational stage and the knowledge area to which the program belongs. For educational stage, the study included students that were very close to finishing their studies and starting their internship. The rationale for this was that students at this stage have some degree of experience and pedagogical knowledge that enables them to provide more informed and thoughtful opinions. For knowledge area, students were distributed into three focus groups per knowledge area with the purpose of encompassing all the teacher training programs: Social Sciences and Arts and Humanities (History and Geography; Spanish Language and Philosophy, and English as a Second Language; Music), Sciences (Mathematics and Physics, Mathematics and Computing, Chemistry and Natural Sciences, Biology and Natural Sciences), and Education (Pre-School Education, General Elementary Education, and Special Education).

It is worth noting that the project funding this research (Fondecyt No. 11180227) and the participant university required the necessary ethical permissions. To comply with this requirement, the university's ethics committee examined the information and issued an ethics certificate authorizing the research on the students. All the students voluntarily participated in the study and signed an informed consent form. The consent provided information about the research and about personal and data privacy.

The focus groups were held in quiet and adequate spaces in the university's own premises between September and October 2019. The main discussion topic during these sessions was the educational research training the 
students are receiving and the students' suggestions for improving it.

Some of the questions asked to the students included:

- What do you think about the educational research training that you have received so far? Have you liked it or not?

- What have you learned from this training?

- How could this training be improved?

- What do you suggest to improve it?

Our data analysis approach takes into consideration many of the principles of Grounded Theory (Glaser \& Strauss, 1967). For this reason, the information was analyzed based on relevant fragments. Before collecting the information, the fragments were coded based on the set of predefined categories and on the categories emerging from the analysis. Then, the codes were arranged and sorted in semantic categories that serve as a sort of organizing theme for the results. The analysis was conducted with support of Atlas ti v8. All the categories and their associated codes are shown in Table 1.

Table 1. Semantic categories and associated codes derived from the data analysis

\begin{tabular}{|c|c|}
\hline Categories & Associated Codes \\
\hline Usefulness of educational research & 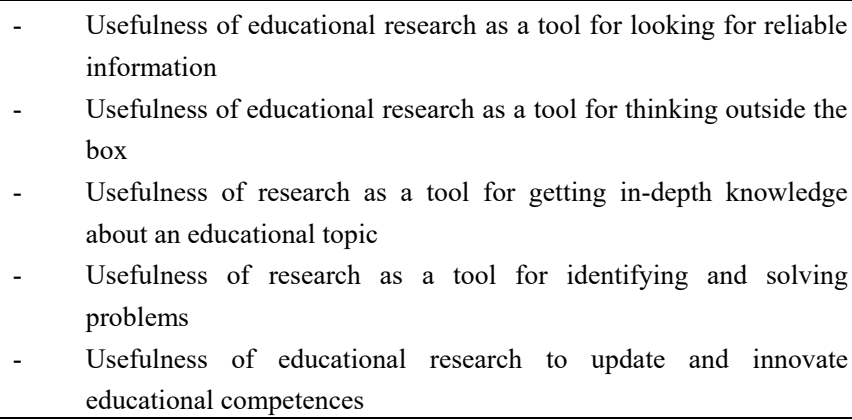 \\
\hline Critical view of educational research training & $\begin{array}{l}\text { - Criticism over the lack of continuity of research-related courses } \\
\text { - Criticism over the low motivation provided by the formal } \\
\text { curriculum to young students who want to become researchers } \\
\text { - Criticism over the limited contact they have had with educational } \\
\text { research during their studies } \\
\text { - Criticism of the overly theoretical approach to educational research } \\
\text { - } \quad \text { Lack of continuous training in research-related subjects }\end{array}$ \\
\hline Suggestions for improving educational research training & $\begin{array}{l}\text { - } \begin{array}{l}\text { Importance of engaging students in research activities } \\
\text { - }\end{array} \text { Importance of sharing and giving visibility to educational research } \\
\text { Importance of having teacher educators who are experienced in } \\
\text { educational research and promote its use } \\
\text { - } \quad \text { Need to create instances for sharing research among students from } \\
\text { this and other universities } \\
\text { - } \quad \text { Suggestion for the university to make students aware of existing } \\
\text { educational research and their producers } \\
\text { - Suggestion to promote the deliberate and permanent inclusion of } \\
\text { educational research into the course of studies } \\
\text { - Suggestion to include an elective course in educational research }\end{array}$ \\
\hline
\end{tabular}

Source (Developed by author).

\section{Results}

Consistent with the semantic categories identified in the data analysis, the findings are analyzed from three perspectives: the usefulness of educational research, the critical view on educational research training, and the suggestions for improving that training. 


\subsection{Usefulness of Educational Research}

The first theme emerging from the students' answers is the usefulness they see in educational research. Overall, the students emphasize certain skills they have developed thanks to the educational research activities they have performed during their studies. These skills include, for example, how to better screen information (going beyond Wikipedia) and how to use the APA citation rules:

I know classmates from other programs who only cut and paste information and don't have the ability to paraphrase, infer or seek reliable information in sites other than Wikipedia or blogs, (...) it has also been useful to learn the APA rules, because other classmates know very little about them. (FG area 3)

Another positive aspect that these future teachers emphasize is that educational research allows them to get a better understanding of certain educational subjects, which may help them to update their knowledge. Some students go even further as to say that educational research is useful to stop relying exclusively on common sense when analyzing educational problems. Similarly, some students say that educational research can be useful to solve problems that may emerge in educational settings.

Research may be useful to identify problems in an educational setting and apply tools to attempt to solve them. (FG area 3)

It may also be useful to immerse oneself in the educational setting in order to know and analyze a problem, and also essential, look for potential solutions. (FG area 2)

Along the same line, some students emphasize the importance that "practical" research activities may have to know the reality of educational institutions from a research-focused perspective. For them, activities such as visiting a school, interviewing a teacher, and witnessing the problems that arise during a class, are more relevant than learning the theory inside the four walls of the university classroom.

Theory will always be more important, but I wish that the reading and listening part was complemented with activities more closely connected with the schools. I remember that in first year we witnessed a class, interviewed a teacher and then analyzed the challenges faced by that teacher. That left an imprint on me, because I remember it up to this day. But I've forgotten much of the research theory (FG area 1).

It should be noted that, though most of the students recognize the importance and usefulness of research for their teaching career, it was the students in the area of Education who recognized greater benefits in it. This may be explained by the fact that one of the teaching programs in this area has a research hotbed where female university educators and students collaborate in research activities. As a result, they may be more involved in these activities and may have a better grasp of certain concepts.

\subsection{Critical View on Educational Research Training}

As shown in the preceding section, most students agree that educational research is of great value for the teaching profession. However, their favorable views change when they are asked about the research-related training they have received as part of their preparation to become teachers. Almost all the students consider that the training they have received so far is poor and fragmented. One of their main criticisms is that their curricula offer a research-related course in the first year of study and then an educational research course only in the final year. They are disconcerted by the lack of research-related courses during the middle years. Some of the concerns expressed by them are:

The teaching programs in this university are not research-focused. Very little is known about this subject. (FG area 1)

Maybe the biggest problems is in the teaching programs' curriculum design, because we are introduced to it [educational training] in first year, then we have a gap in the subsequent years, and then we return to it only in fourth year when we are about to finish our studies. (FG area 1)

This discontinuous and inconsistent training make the students feel that they are unlikely to do educational research once they become practicing teachers.

They are very specific topics that have not enough consistency for us to acquire the relevant long-term knowledge necessary to conduct research after we graduate. (FG area 1)

Students are also critical of the lack of dissemination of the educational research produced within their own universities and country. They also point out that they lack enough opportunities to participate in research projects and that research participation is limited to a very specific circle of people. Some students even mention they are participating in a research, but only because they were personally invited to take part in it by the 
professor in charge of the project. They feel happy for having been selected, but they recognize that it did not result from an open call made to all the students.

Maybe the university should include students more, because we know that this university produces a lot of research, but I believe that we know very little about what is being researched, particularly in the field of Education. (FG area 3)

We are taking part in Mr. Thomas' project [fictitious name], but it was because he invited us-it was not something that was announced to all the students. (FG area 3)

By contrast, the students in the area of Sciences feel that their research experiences in their areas of specialization (biology, chemistry, physics or maths) have been very different and of higher quality compared to those in their pedagogical training courses. According to them, their specialization areas have been more deliberate regarding research activities and they feel they are better prepared to conduct such specialized research. They do not feel that same certainty regarding educational research.

(...) if you were to ask me what I feel prepared for, either educational research or research in natural sciences, I would undoubtedly say research in sciences. Because I already know how to do it. Educational research would be very difficult for me. (FG area 2)

Students are also critical of their teachers' own research experience and the guidance they have provided for certain research activities. Though they recognize that some teachers have research training and are motivated to introduce educational research activities, they note that this is not what happens in the majority of cases. Some students think that if their teachers have no training or experience in education-related research, it is unlikely that these will promote its use and consumption.

To be honest, it is obvious to everyone that some teachers are not very much involved in educational research and you can immediately tell the difference compared to the teachers in our specialization. Not all of them have Ph.D.'s or are involved in projects or conferences, or things like that. (FG area 2)

If teachers are not interested in educational research, I don't think they will teach us things related to the subject. The lessons could be more fun if, for example, we read research articles. (FG area 2)

Another side to this criticism is the limited and confusing guidance that some teachers have provided to the students when conducting research. Some students were left with bad memories of a course in which the teacher asked them to collect data in a socially vulnerable part of the city where they felt scared and confused. The fact that they received no explanation on how to proceed made them over time develop an aversion to the course and to the notion of educational research.

I remember that a teacher sent us to a school in a vulnerable neighborhood, but he didn't explain us anything nor he informed the community that we would go there. We had to knock on doors, and many people closed their doors on our faces. The same happened when we went to a school. We had to explain the principal why we were there. The teacher didn't provide us with a formal letter, for example. (FG area 3)

\subsection{Suggestions for Improving Educational Research Training}

The third theme emerging from the analysis is the students' suggestions for improving the research-related training they are receiving. These suggestions encompass different aspects that are closely linked to the criticisms they have expressed.

Their first suggestion is giving educational research a more deliberate presence within the program courses, starting in the first year of study. This would help address the criticism expressed regarding the lack of research-related courses and the limited connection between them.

A suggestion would be to go deeper into the subject in the Education courses, because some contents are lost in the curriculum during the course of our studies, and you should be constantly reinforcing contents. I'm saying that we should have at least one course a year promoting educational research. (FG area 3)

Research should be addressed from the beginning of the program so that we have no time gaps as we previously mentioned. (FG area 2)

In addition to the courses that are part of the curriculum, students also suggest including elective courses that they could take voluntarily over time. In the university where this study was conducted, it is mandatory to take a few elective course credits, for which reason some of the students consider it would be useful to include educational research in the semester course offer. 
Maybe three or four elective courses could be offered from first year, one of them related to educational research. It might be interesting and more useful than some other elective courses in offer that are typically of no use. (FG area 1)

On a different but related note, some students suggest including activities such as reading and reviewing research articles in all the Education courses. This involves more than learning specific educational research-related content in specific courses, it involves incorporating research across all the program. This suggestion is also related to the criticism that university teachers must be better trained in educational research and has a more open attitude towards its use in class.

(...) that in each course, for example, Evaluation Theory and Instructional Design, they could have shown us some research, that way we can gradually begin to learn about educational research. Later, we could have arrived at Research Methods with more knowledge, because I felt very lost when I took that course. (FG area 2)

(...) the teachers must be better prepared. They must be teachers who publish research or take part in conferences or other similar activities. (FG area 2)

Another suggestion made by the students is that the university should promote the dissemination of educational research and greater student participation in research activities. In general, the students feel that the educational research produced within their university stays on paper and is not made known to the wider university community. To address this they suggest conducting more seminars, talks, symposiums or conferences open to student participation. Similarly, they think that more collaborative research projects between university researchers and teaching students should be promoted. The students believe that, should those projects exist, the process used to inform the student community should be improved in order to promote student participation.

One suggestion may to promote collaborative research between teachers and students while at the same time offering more project contests for us to participate. (FG area 1)

The students also suggest that the university should promote student participation in activities aimed at sharing educational research with students from other universities. This could be done through conferences or inter-university meetings where research could be presented and students could have the opportunity to interact.

We've seen that in our area of specialization conferences are held in which students can participate. But we don't see that in the area of Education. It would be great if we had the chance to interact with students from other universities and share the research produced in our institutions. (FG area 1)

\section{Discussion}

The first relevant theme emerging from this study is how important is the students' educational plan for educational research training to occur, especially from the first years of study. This is what the participants clearly expressed. If educational research becomes relevant in the curriculum, students are more likely to use it and know its benefits. These findings are consistent with work by authors such as Demircioglu (2008), Anwaruddin and Pervin (2015), Perines and Murillo (2017), and Agud and Ion (2019). Indeed, this latter research mentions the importance of the decisions made by the faculties involved in teacher training. This aspect is linked to what has been mentioned here regarding the decisions that the university must make to make research more accessible, create participation opportunities, and give educational research more prominence in the program. It is precisely the access to educational research one of the aspects discussed in this research, not in terms of access to research articles or databases but in terms of opportunities to engage in research, which according to the future teachers is restricted to a very select group of people. These findings are consistent with McCartney, Marwick, Hendry, and Ferguson (2018) and are linked to the issue of access to knowledge discussed by Neary and Winn (2009). The democratization of the knowledge produced through research is a relevant aspect emerging from this study.

Another aspect of note in this discussion is that the future teachers are aware of several of the benefits delivered by educational research activities. For instance, this work shows that educational research activities help improve the professional competences of future teachers, making them more aware of their own learning and of the source of their knowledge, as suggested by authors such as Reis-Jorge (2005), Levy and Petrulis (2012), and Guilbert et al. (2016).

Finally, it is worth mentioning that the study participants are not as skeptical of the usefulness of educational research for professional practice compared to findings in previous research (e.g., van Katwijk et al., 2019; Puustinen et al., 2018). However, there is consensus that research activities that are closely linked to practice can be more relevant for students, as Damşa (2018) suggests. 


\section{Conclusions}

The two objectives of this research were to explore the views of future teachers about the research training they are receiving and know their suggestions for improving it.

Regarding the first research objective, this study evidences that although the future teachers highly value educational research, they believe that the training they are receiving has considerable weaknesses. They highly value the work of some of their teachers and feel they have acquired new knowledge and tools as part of the courses they have taken, but they think there is little continuity between the instances where educational research is taught. They also believe that there are weaknesses in their educators' educational research training and that more instances of participation are needed. If these findings are analyzed from the perspective of the study areas of the participants, it could be said that the students in the area of Education were more aware of the benefits of educational research. Apart from this, no significant differences of opinion between areas were observed.

Regarding the second research objective, the suggestions made by the future teachers are highly significant. Despite their critical views, the students are aware of the importance that educational research may have in their professional preparation. Beyond these suspicious views, they show willingness and intention to change this situation and optimize their engagement in research activities. The future teachers want to have more opportunities to engage in research, e.g., by taking part in projects and being informed of contests in a timely manner; being informed of the educational research produced within their university, and joining inter-university initiatives related to this subject. The students hope this will start to change so that the new generations will be equipped with better tools. In this respect, it is worth noting that the teacher training programs in this university have started renovating their curricula starting in 2019. This change opens a promising door, at least as far as the number of educational research-related courses is concerned. However, the suggestions put forward here call for more radical changes. An example of that are the abilities that teacher educators should possess for true educational research training to exist. This is a very relevant and sensitive topic within universities which can not be solved by simply adding courses to the curriculum. I say sensitive, because it is not easy to effect changes among university teachers in a highly competitive environment. Educational research is core to teacher training, encompassing not only research-related courses, but also other courses and extracurricular activities, as well as an open attitude towards the subject by all the faculty students and authorities.

The main strengths of this research are, on the one hand, the novel approach used to explore the suggestions made by the future teachers, which is a topic that has not been widely studied. On the other hand, this research contributes to the current literature on the subject, which despite containing important works and international authors, requires more study and analysis. For this reason, it is important to take into account what happens with this topic in developing countries. Some of the study weaknesses are that the selection of participants may partially bias the results since in most cases the subjects were people interested in participating. Though it is true that in qualitative studies informants are not usually randomly selected, it is important to recognize this weakness. This problem could be addressed by linking the qualitative and the quantitative approaches through the administration of a questionnaire to the focus groups. Another weakness is that the study was conducted in a single university, though this could be addressed by including other institutions and even comparing public and private universities.

Finally, it is to be hoped that the authorities and educational stakeholders responsible for the professional programs take into consideration the future teachers' suggestions for improving educational research training. If we want to improve professional training systems and, more importantly, teacher professional training, we must listen to the students and explore their views. As the work of teachers is critical for the education of the children and youth, it is essential to invest time and resources on it.

\section{Acknowledgments}

This research shows some results of the Initiation FONDECYT Project 11180227 "Presence and importance of integrating research in teaching education and how it is perceived by students and lecturers" awarded to the author and funded by the "National Research and Development Agency" (ANID-Chile).

\section{References}

Agud, I., \& Ion, G. (2019). Research-Based Learning in Initial Teacher Education in Catalonia. Center for Educational Policy Studies Journal, 9(2), 99-118. https://doi.org/10.26529/cepsj.564

Anwaruddin, S. M., \& Pervin, N. (2015). English-language teachers' engagement with research: Findings from Bangladesh. Professional Development in Education, 41(1), 21-39. https://doi.org/10.1080/19415257.2013.861860 
Ashwin, P. (2014). Knowledge, curriculum and sudent undersanding. Higher Education, 67(2). https://doi.org/10.1007/s10734-014-9715-3

Aspfors, J., \& Eklund, G. (2017). Explicit and implicit perspectives on research-based teacher education: newly qualified teachers' experiences in Finland. Journal of Education for Teaching, 43(4), 400-413.

Barnett, R. (2009). Knowing and becoming in higher education. Studies in Higher Education, 34(4), 429-440. https://doi.org/10.1080/03075070902771978

Cain, T., \& Allan, D. (2017). The invisible impact of educational research. Oxford Review of Education, 43(6), 718-732. https://doi.org/10.1080/03054985.2017.1316252

Damşa, C. (2018). Research and Development Tasks in Teacher Education: Institutional Framing and Student Experiences. In Reconfiguring Knowledge in Higher Education (pp. 149-167). Cham, Switzerland: Springer. https://doi.org/10.1007/978-3-319-72832-2_9

Demircioglu, I. H. (2008). Learning How to Conduct Educational Research in Teacher Education: A Turkish Perspective. Australian Journal of Teacher Education, 33(1), 1-17. https://doi.org/10.14221/ajte.2008v33n1.1

Dunn, M., Harrison, L. J., \& Coombe, K. (2008). In good hands: Preparing research-skilled graduates for the early childhood profession. Teaching and Teacher Education, 24(3), 703-714. https://doi.org/10.1016/j.tate.2007.09.002

Glaser, B., \& Strauss, A. (1967). The discovery of grounded theory: Strategies for Qualitative Research. London, UK: Weidenfield \& Nicolson. https://doi.org/10.1097/00006199-196807000-00014

Goodyear, P., \& Zenios, M. (2007). Discussion, collaborative knowledge work and epistemic fluency. British journal of educational studies, 55(4), 351-368. https://doi.org/10.1111/j.1467-8527.2007.00383.x

Griffioen, D. M. E., Groen, A., \& Nak, J. (2019). The Integration of Research in the Higher Education Curriculum: A Systematic Review. The Higher Education Journal of Learning and Teaching, 10(1). https://doi.org/10.24384/vhs6-1j85

Guilbert, D., Lane, R., \& Van Bergen, P. (2016). Understanding student engagement with research: A study of pre-service teachers' research perceptions, research experience, and motivation. Asia-Pacific Journal of Teacher Education, 44(2), 172-187. https://doi.org/10.1080/1359866X.2015.1070118

Haberfellner, C., \& Fenzl, T. (2017). The utility value of research evidence for educational practice from the perspective of preservice student teachers in Austria-A qualitative exploratory study. Journal for Educational Research Online, 9(2), 69-87.

Healey, M., \& Jenkins, A. (2009). Developing students as researchers. Special Publication, no. 1. In S. K. Haslett, \& H. Rowlands (Eds.), Proceedings for the Newport NEXUS Conference (pp. 7e11). Centre for Excellence in Learning and Teaching.

Huizinga, T., Handelzalts, A., Nieveen, N., \& Voogt, J. M. (2014). Teacher involvement in curriculum design: Need for support to enhance teachers' design expertise. Journal of curriculum studies, 46(1), 33-57. https://doi.org/10.1080/00220272.2013.834077

Ion, G. (2014). Teachers as rese arch promoters. In M. Schratz, M. Pecek, \& R. Iucu (Eds.), The changing role of teachers (pp. 196-218). Bucharest, Romania: Ars Docendi.

Levy, P., \& Petrulis, R. (2012). How do first-year university students experience inquiry and research, and what are the implications for the practice of inquiry-based learning? Studies in Higher Education, 37(1), 85-101. https://doi.org/10.1080/03075079.2010.499166

Macdonald, M., Badger, R., \& White, G. (2001). Changing values: what use are theories of language learning and teaching? Teaching and Teacher Education, 17(8), 949-963. https://doi.org/10.1016/S0742-051X(01)00042-7

McCartney, E., Marwick, H., Hendry, G., \& Ferguson, E. C. (2018). Eliciting student teacher's views on educational research to support practice in the modern diverse classroom: A workshop approach. Higher Education Pedagogies, 3(1), 342-372. https://doi.org/10.1080/23752696.2018.1498748

Murillo, F. J., Perines, H., \& Lomba, L. (2017). La comunicación de la investigación educativa. Una aproximación a la percepción de los artículos académicos y de difusión por parte de docentes no universitarios. Profesorado. Revista de Curriculum y Formación de Profesorado, 21(3). 
Neary, M., \& Winn, J. (2009). The student as producer: reinventing the student experience in higher education. In L. Bell, H. Stevenson, \& M. Neary (Eds.), The future of higher education: policy, pedagogy and the student experience (pp. 192-210). London, UK: Continuum

Perines, H. (2018). Por qué la investigación educativa no impacta en la práctica docente? Estudios sobre Educación, 34, 9-27. https://doi.org/10.15581/004.34.9-27

Perines, H., \& Campaña, K. (2019). La alfabetización de los futuros docentes en investigación educativa: Una reflexión teórica desde el contexto de Chile. Revista Caribeña de Investigación Educativa (RECIE), 3(1), 7-18. https://doi.org/10.32541/recie.2019.v3i1.pp7-18

Perines, H., \& Murillo, F. J. (2017a). Percepciones de los docentes en formación sobre la investigación educativa. Estudios Pedagógicos (Valdivia), 43(1), 251-268. https://doi.org/10.4067/S0718-07052017000100015

Perines, H., \& Murillo, F. J. (2017b). Cómo mejorar la investigación educativa? Sugerencias de los docentes. Revista de la Educación Superior, 46(181), 89-104. https://doi.org/10.1016/j.resu.2016.11.003

Puustinen, M., Säntti, J., Koski, A., \& Tammi, T. (2018). Teaching: A practical or research-based profession? Teacher candidates' approaches to research-based teacher education. Teaching and Teacher Education, 74, 170-179. https://doi.org/10.1016/j.tate.2018.05.004

Reis-Jorge, J. M. (2005). Developing teachers' knowledge and skills as researchers: A conceptual framework. Asia-Pacific Journal of Teacher Education, 33(3), 303-319. https://doi.org/10.1080/13598660500286309

Rodríguez, G., Gil, J., \& García, E. (1999). Metodología de la investigación cualitativa. Málaga, Spain: Aljibe.

Todd, M., Bannister, P., \& Clegg, S. (2004). Independent inquiry and the undergraduate dissertation: perceptions and experiences of final-year social science students. Assessment \& Evaluation in Higher Education, 29(3), 335-355. https://doi.org/10.1080/0260293042000188285

Ulvik, M. (2014). Student-teachers doing action research in their practicum: Why and how? Educational Action Research, 22(4), 518-533. https://doi.org/10.1080/09650792.2014.918901

Van der Linden, W., Bakx, A., Ros, A., Beijaard, D., \& Vermeulen, M. (2012). Student teachers' development of a positive attitude towards research and research knowledge and skills. European Journal of Teacher Education, 35(4), 401-419. https://doi.org/10.1080/02619768.2011.643401

Van Katwijk, L., Berry, A., Jansen, E., \& van Veen, K. (2019). "It's important, but I'm not going to keep doing it!": Perceived purposes, learning outcomes, and value of pre-service teacher research among educators and pre-service teachers. Teaching and Teacher Education, 86. https://doi.org/10.1016/ j.tate.2019.06.022

Young, M. (2014). What is a curriculum and what can it do? The Curriculum Journal, 25(1), 7-13. https://doi.org/10.1080/09585176.2014.902526

\section{Copyrights}

Copyright for this article is retained by the author(s), with first publication rights granted to the journal.

This is an open-access article distributed under the terms and conditions of the Creative Commons Attribution license (http://creativecommons.org/licenses/by/4.0/). 